tice. It is a fact which will create surprise when we state it, that not one of the Iowa executive departments has a complete file of its own reports, nor do they possess the original copies. These reports are made to the Governor and, in accordance with the statute, are sent to the State printer. When the document is put inte type and the proofs read and compared, the original copy goes into the waste basket and that is the end of it. In a few years the last printed copy is distributed, or borrowed and never returned, and so the continuity of the history of a department is interrupted and lost, often beyond recovery. When the old Capitol was burned a few years ago hundreds if not thousands of precious historical papers went up in the flames. We cannot recover what has been lost, but we may gather up what remains, make adequate provision for accruing archives, and preserve them with jealous care. To effect these high purposes an "Iowa Hall of Archives" is an absolute necessity.

\title{
REPRINTING THE OLD ANNALS OF IOWA.
}

On the 31st of March, 1900, Senator Penrose of Tama county introduced the following preamble and resolution looking to reprinting the First and Second Series of THE Annals of Iowa, which were originally published at Iowa City. The purpose in view is to print a suffcient number of this periodical to supply the libraries of our State each with a copy, as well as for exchanges with other states. The resolution passed both branches of the General Assembly without a dissenting vote:

Whrneas, The historical magazine known as "The Annals of Iowa," was commenced by the State Hietorical Society, at Iowa City, in January, 1863, and continued until October, 1874; and,

Whereas, Said publication has long been out of print and impossible to be obtained; and,

Wreneas, It is deemed most desirable that the public libraries, schools and colleges of this State shall each possess a copy of said work, as em- 
bodying more of our history than can at present be found in any other form; therefore,

Resolved, (by the Senate, the House concurring): That the Trustees of the Iowa State Library and the Historical Department be, and they are hereby requested to make inquiries and report at the next session of the Legislature apon what terms said work can be republished by the State, and the cost thereof, for an edition of 1,000 copies.

This action gives a strong evidence of the interest which is now rapidly developing in our State in favor of improving every facility for the study of Iowa and western history. It will be noticed that this movement is not directed to the narrow purpose of benefitting any one interest or locality, but to place this very scarce and now most precious historical work in libraries throughout the State. The history of Iowa is one of which every citizen may well be proud, but up to this time it only exists in the shape of scattered materials for such a work. We believe that the next two or three years will see books published which will vastly widen this department of our knowledge. In that time the public will doubtless be able to see and appreciate more fully the labors of Dr. Wm. Salter, Jesse Macy, B. F. Gue, B. F. Shambaugh, F. I. Herriott, and perbaps others, who are now striving to bring something like order out of the chaos of the past fifty years.

\section{TWO INTERESTING PAPERS.}

Mr. J. T. Fields, of Omaha, Nebraska, has deposited in the Historical Department the original copies of two papers discharging William Bratton from the military service of the United States. He was first a member of the famous Lowis and Clark Expedition from St. Louis to the mouth of the Columbia River (1804-6). This expedition returned to St. Louis in September, 1806, and the discharge was dated a few days later. This paper seems to be in the handwriting of Capt. Meriwether Lewis, by whom it is signed in two places. It is more than usually interesting from the fact that it is all 
Copyright of Annals of Iowa is the property of State of Iowa, by \& through the State Historical Society of Iowa and its content may not be copied or emailed to multiple sites or posted to a listserv without the copyright holder's express written permission. However, users may print, download, or email articles for individual use. 